University of Nebraska - Lincoln

DigitalCommons@University of Nebraska - Lincoln

US Department of Energy Publications

U.S. Department of Energy

2003

\title{
Inhibition of Bacterial U(VI) Reduction by Calcium
}

Scott Brooks

Oak Ridge National Laboratory, brookssc@ornl.gov

James K. Fredrickson

Pacific Northwest National Laboratory, jim.fredrickson@pnl.gov

Sue Carroll

Oak Ridge National Laboratory

David Kennedy

Pacific Northwest National Laboratory

John M. Zachara

Pacific Northwest National Laboratory, john.zachara@pnl.gov

See next page for additional authors

Follow this and additional works at: https://digitalcommons.unl.edu/usdoepub

Part of the Bioresource and Agricultural Engineering Commons

Brooks, Scott; Fredrickson, James K.; Carroll, Sue; Kennedy, David; Zachara, John M.; Plymale, Andrew; Kelley, Shelly; Kemner, Kenneth; and Fendorf, Scott, "Inhibition of Bacterial U(VI) Reduction by Calcium" (2003). US Department of Energy Publications. 223.

https://digitalcommons.unl.edu/usdoepub/223

This Article is brought to you for free and open access by the U.S. Department of Energy at DigitalCommons@University of Nebraska - Lincoln. It has been accepted for inclusion in US Department of Energy Publications by an authorized administrator of DigitalCommons@University of Nebraska - Lincoln. 


\section{Authors}

Scott Brooks, James K. Fredrickson, Sue Carroll, David Kennedy, John M. Zachara, Andrew Plymale, Shelly Kelley, Kenneth Kemner, and Scott Fendorf 


\section{Inhibition of Bacterial U(V) Reduction by Calcium}

\author{
SCOTTC. BROOKS,*, \\ JAMES K. FREDRICKSON, \\ SUE L. CARROLL, ${ }^{\dagger}$ DAVID W. KENNEDY, ${ }^{\ddagger}$ \\ JOHN M. ZACHARA, \\ ANDREW E. PLYMALE, $\neq$ \\ SHELLY D. KELLY, § \\ KENNETH M. KEMNER, \& AND \\ SCOTT FENDORF"
}

Environmental Sciences Division, P.O. Box 2008,

MS 6038, Oak Ridge National Laboratory,

Oak Ridge, Tennessee 37831-6038, Pacific Northwest National

Laboratory, P.O. Box 999, Richland, Washington 99338,

Argonne National Laboratory, 9700 South Cass Avenue,

Argonne, Illinois 60439-4843, and Department of Geological and Environmental Sciences, Stanford University,

Stanford, California 94305-2115

The rapid kinetics of bacterial $\mathrm{U}(\mathrm{VI})$ reduction and low solubility of uraninite $\left(\mathrm{UO}_{2, \mathrm{cr}}\right)$ make this process an attractive option for removing uranium from groundwater. Nevertheless, conditions that may promote or inhibit U(VI) reduction are not well-defined. Recent descriptions of $\mathrm{Ca}-\mathrm{UO}_{2}-$ $\mathrm{CO}_{3}$ complexes indicate that these species may dominate the aqueous speciation of $U(V I)$ in many environments. We monitored the bacterial reduction of $\mathrm{U}(\mathrm{VI})$ in bic arbonatebuffered solution in the presence and absence of $\mathrm{Ca}$. XAFS measurements confirmed the presence of a $\mathrm{Ca}-$ $\mathrm{U}(\mathrm{VI})-\mathrm{CO}_{3}$ complex in the initial solutions containing calcium. Calcium, at millimolar concentrations $(0.45-5 \mathrm{mM})$, caused a significant decrease in the rate and extent of bacterial U(VI) reduction. Both facultative (Shewanella putrefaciens strain CN 32) and obligate (Desulfovibrio desulfuricans, Geobacter sulfurreducens) anaerobic bacteria were affected by the presence of calcium. Reduction of $\mathrm{U}(\mathrm{VI})$ ceased when the calculated system $E_{\mathrm{h}}$ reached -0.046 $\pm 0.001 \mathrm{~V}$, based on the $\mathrm{Ca}_{2} \mathrm{UO}_{2}\left(\mathrm{CO}_{3}\right)_{3} \rightarrow \mathrm{UO}_{2, \text { cr couple. }}$ The results are consistent with the hypothesis that $U$ is a less energetically favorable electron acceptor when the $\mathrm{Ca}-$ $\mathrm{UO}_{2}-\mathrm{CO}_{3}$ Complexes are present. The results do not support $\mathrm{Ca}$ inhibition caused by direct interactions with the cells or with the electron donor as the reduction of fumarate or $\mathrm{Tc}(\mathrm{VII}) \mathrm{O}_{4}{ }^{-}$under identical conditions was unaffected by the presence of $\mathrm{Ca}$.

\section{Introduction}

Dissimilatory metal-reducing bacteria (DMRB) couple the oxidation of organic matter or $\mathrm{H}_{2}$ to the reduction of oxidized metals. Bacterial respiration based on the reduction of Fe(III) and $\mathrm{Mn}(\mathrm{III} / \mathrm{IV})$ is an important process in the cycling of

\footnotetext{
*Corresponding author telephone: (865)574-6398; fax: (865)5768646; e-mail: brookssc@ornl.gov.

† Oak Ridge National Laboratory.

₹ Pacific Northwest National Laboratory.

$\S$ Argonne National Laboratory.

" Standord University.
}

carbon and these metals in the environment (1-3). In recent years, a significant body of work has shown that DMRB can also reduce a number of toxic metals and radionuclides of environmental concern including $\mathrm{Co}(\mathrm{III})$-EDTA, $\mathrm{Cr}(\mathrm{VI})$, $\mathrm{Tc}(\mathrm{VII})$, and $\mathrm{U}(\mathrm{VI})(4-12)$. From the standpoint of remediation of contaminated environments, the bacterial reduction of these metals is desirable as the lower oxidation states are less stable (Co-EDTA), less mobile, and have a lower solubility than when present at higher oxidation states.

Activities associated with the mining and processing of uranium (U) ores as well as defense-related activities have resulted in vast areas of contaminated soils and groundwater. Oxidized uranium $(\mathrm{U}(\mathrm{VI}))$ is much more soluble than the reduced form $(\mathrm{U}(\mathrm{IV}))$ and typically exists in groundwater as uranyl carbonate complexes. $\mathrm{U}(\mathrm{VI})$ is readily reduced by DM RB under anoxic conditions, resulting in the precipitation of uraninite $\left(\mathrm{U}(\mathrm{IV}) \mathrm{O}_{2, \mathrm{cr}}\right)(4,5)$. The rapid rate of $\mathrm{U}(\mathrm{VI})$ reduction and the low solubility of U(IV) makes bioremediation an attractive option for removing $U$ from contaminated groundwaters.

Despite the promise of bioreduction as a remediation strategy, the factors that may enhance or inhibit bacterial $\mathrm{U}(\mathrm{VI})$ reduction under environmental conditions are not welldefined. Previous research has shown that microbial reduction of $U$ is difficult to predict and that results obtained under a particular set of conditions or by a particular microorganism are not necessarily transferable to other conditions or organisms. For example, the rate of $\mathrm{U}(\mathrm{VI})$ reduction by Shewanella al gaestrain $\mathrm{BrY}$ increased as $\mathrm{U}(\mathrm{VI})$ was complexed by multidentate organic ligands while $U$ complexation by the same ligands decreased the rate of $U(\mathrm{VI})$ reduction by Desulfovibrio desulfuricans (13). Phillips et al. (14) reported that $U(\mathrm{VI})$ reduction by $\mathrm{D}$. desulfuricans decreased as the concentration of bicarbonate was increased from 30 to 100 $\mathrm{mM}$. The rate and extent of $\mathrm{U}(\mathrm{VI})$ removal from solution by D. desulfuricans decreased in the presence of sulfate $\left(\mathrm{SO}_{4}{ }^{2-}\right)$ or nitrate $\left(\mathrm{NO}_{3}{ }^{-}\right)$at concentrations of 104 and $806 \mathrm{mM}$, respectively (15). The bacterial removal of $\mathrm{U}(\mathrm{VI})$ from water is also inhibited by the presence of competitive electron acceptors, such as iron(III) (hydr)oxides (16) and also inhibited by the presence of geochemical oxidants, such as manganese(IV) oxides (17, 18).

Most equilibrium speciation models predict that the dominant $\mathrm{U}(\mathrm{VI})$ aqueous species in groundwater will be uranyl carbonate complexes $(19,20)$. Nevertheless, $\mathrm{Ca}-\mathrm{U}-$ $\mathrm{CO}_{3}$ complexes $\left(\mathrm{CaUO}_{2}\left(\mathrm{CO}_{3}\right)_{3}{ }^{2-}, \mathrm{Ca}_{2} \mathrm{UO}_{2}\left(\mathrm{CO}_{3}\right)_{3}\right)$ haverecently been described (21-23) that havegenerally not been included in the speciation calculations. The magnitude of the formation constants for these species $\left(\log \beta_{113}=25.4 ; \log \beta_{213}=\right.$ 30.55) suggests that they should beimportant aqueous species in many natural and contaminated environmental settings. For example, Abdelouaset al. (20) calculated theU(VI) species distribution in groundwater from the Tuba City, AZ, U ranium Mill Tailing Remedial Action (UMTRA) site. They reported that the species $\mathrm{UO}_{2}\left(\mathrm{CO}_{3}\right)_{2}{ }^{2-}$ and $\mathrm{UO}_{2}\left(\mathrm{CO}_{3}\right)_{3}{ }^{4-}$ account for $56 \%$ and $38 \%$, respectively, of the aqueous $\mathrm{U}(\mathrm{VI})$. U sing the reported water composition and recalculating the species distribution including the $\mathrm{Ca}-\mathrm{U}(\mathrm{VI})-\mathrm{CO}_{3}$ species indicates that $\mathrm{Ca}_{2} \mathrm{UO}_{2}\left(\mathrm{CO}_{3}\right)_{3, \mathrm{aq}}$ and $\mathrm{CaUO}_{2}\left(\mathrm{CO}_{3}\right)_{3}{ }^{2-}$ account for $99.3 \%$ and $0.3 \%$, respectively, of the $\mathrm{U}(\mathrm{VI})$ whereas $\mathrm{UO}_{2}\left(\mathrm{CO}_{3}\right)_{2}{ }^{2-}$ and $\mathrm{UO}_{2}\left(\mathrm{CO}_{3}\right)_{3}{ }^{4-}$ combined account for less than $0.4 \%$ of the uranium. The $\mathrm{Ca}_{2} \mathrm{UO}_{2}\left(\mathrm{CO}_{3}\right)_{3}$ complexmay play an important rolein theenvironmental chemistry of U. Its potential impact on bacterial $\mathrm{U}(\mathrm{VI})$ reduction has not been addressed to date. This paper reports on the systematic investigation of the influence of $\mathrm{Ca}$ on the bacterial reduction of $\mathrm{U}(\mathrm{VI})$. 


\section{Materials and Analytical Methods}

Cell Culturing and Harvesting. One facultative bacterium (Shewanella putrefaciens strain CN32) and two strict anaerobes (Desulfovibrio desulfuricans and Geobacter sulfurreducens) were used to evaluate the effects of $\mathrm{Ca}$ on bacterial $U$ reduction. All of these bacteria wereisolated from anaerobic sediments and are effective at enzymatically reducing $\mathrm{U}(\mathrm{VI})$ to U(IV). S. putrefaciens strain CN32 was provided courtesy of Dr. David Boone (Subsurface Microbial CultureCollection, Portland State University, Portland, OR). Strain CN32 was isolated from a subsurface core sample ( $250 \mathrm{~m}$ beneath the surface) from the Morrison Formation in northwestern New Mexico (24). CN32 was routinely cultured aerobically in tryptic soy broth (TSB), $30 \mathrm{~g} / \mathrm{L}$ (Difco Laboratories, Detroit, $\mathrm{MI}$ ), and stock cultures were maintained by freezing in $40 \%$ glycerol at $-80^{\circ} \mathrm{C}$.

S. putrefaciens CN32 was grown aerobically in $250-\mathrm{mL}$ Erlenmeyer flasks with $100 \mathrm{~mL}$ of TSB. Cultures were incubated for $16 \mathrm{~h}$ on a rotary shaker $(100 \mathrm{rpm})$ at $30^{\circ} \mathrm{C}$. Cells were harvested by centrifugation $\left(6000 \mathrm{~g}, 15 \mathrm{~min}, 4{ }^{\circ} \mathrm{C}\right)$, washed once in $30 \mathrm{mM}$ PIPES buffer ( $\mathrm{pH} 7)$ and once with $30 \mathrm{mM}$ sodium bicarbonate, and resuspended in $60 \mathrm{~mL}$ of $30 \mathrm{mM}$ sodium bicarbonate that was made anoxic by purging with $\mathrm{N}_{2}: \mathrm{CO}_{2}$ (80:20). Cells were resuspended in a volume sufficient to achieve a concentration of about $2-4 \times 10^{9}$ cells/mL. For comparative purposes, S. putrefaciens CN32 was also grown anaerobically in a chemically defined medium (NB basal) (25) with $40 \mathrm{mM}$ fumarateas theelectron acceptor and $20 \mathrm{mM}$ sodium lactate as the electron donor. Cells were harvested and washed as described above for aerobically grown cultures. Because of the lower biomass yield from these anaerobic cultures, only $5 \times 10^{7} \mathrm{cell} / \mathrm{s} / \mathrm{mL}$ were used for the final concentration. Cells werestored on iceand used within $4 \mathrm{~h}$

D. desulfuricans was grown anaerobically in $100 \mathrm{~mL}$ Modified Starkey's Medium C (ATCC Medium 207) with sodium sulfate substituted for ferrous ammonium sulfate and an $\mathrm{N}_{2}$ headspace. Cultures were incubated for $48 \mathrm{~h}$ on a rotary shaker $(100 \mathrm{rpm})$ at $30^{\circ} \mathrm{C}$. Cells were harvested by centrifugation and washed in anaerobic PIPES and bicarbonate buffers as described above. Cells were resuspended in $30 \mathrm{mM}$ sodium bicarbonate to $5-8 \times 10^{8}$ cells $/ \mathrm{mL}$ and diluted to a final concentration of $(5-8) \times 10^{7} \mathrm{cell} / \mathrm{s} / \mathrm{mL}$.

G. sulfurreducens was grown in a chemically defined medium (NB basal) (25) with $40 \mathrm{mM}$ fumarateastheterminal electron acceptor and $20 \mathrm{mM}$ sodium acetate as the electron donor. Cultures were incubated for $48 \mathrm{~h}$ on a rotary shaker (100 rpm) at $30^{\circ} \mathrm{C}$. Cells were harvested as described above and resuspended at $9 \times 10^{7}$ cells/ $\mathrm{mL}$ final concentration.

Bacterial U(V) and Tc(VI) Reduction. Reaction vessels for experiments were either $25-\mathrm{mL}$ pressure tubes or $60-\mathrm{mL}$ serum bottles. The reduction of $\mathrm{U}(\mathrm{VI})$, from uranyl acetate, by metal-reducing bacteria was evaluated in the presence and absence of calcium. The base solution consisted of anaerobic $30 \mathrm{mM} \mathrm{NaHCO} 3$ under a headspace of $\mathrm{N}_{2}: \mathrm{CO}_{2}$ (80: 20), pH 6.9. The electron donors lactate (from either sodium lactateor $\mathrm{Ca}(\text { lactate) })_{2}$ ) or acetate (sodium acetate) wereadded from stock solutionsto achieve final concentrations of $5 \mathrm{mM}$. The effect of electron donor was evaluated in select experiments by adding $10 \mathrm{~mL}$ of $\mathrm{H}_{2}$ gas to the headspace in place of lactate. Calcium concentrations were varied via the addition of $\mathrm{CaCl}_{2}$ or $\mathrm{Ca}$ (lactate) $)_{2}$. All reduction studies were conducted at $30^{\circ} \mathrm{C}$ with gyratory shaking.

Tc(VI) Reduction. S. putrefaciens CN32 cells were cultured and harvested as described aboveand resuspended at a final concentration of $2-4 \times 10^{7} / \mathrm{mL}$ in $30 \mathrm{mM} \mathrm{NaHCO}_{3}$ under a headspace of $\mathrm{N}_{2}: \mathrm{CO}_{2}(80: 20)$ to obtain a final $\mathrm{pH}$ of 6.9. $\mathrm{NH}_{4} \mathrm{Tc}(\mathrm{VII}) \mathrm{O}_{4}$ (Amersham Life Sciences Products, Arlington Heights, IL) was added to approximately $50 \mu \mathrm{M}$.
Analyses. At selected time points, samples were taken in an anaerobic glovebag using needles and syringes. The reduction of $U$ was determined by measuring the loss of $\mathrm{U}(\mathrm{VI})$ from solution using a kinetic phosphorescence analyzer (Chemcheck, Ins., Richland, WA) as described previously (5). The reduction of technetium was evaluated by direct extraction and liquid scintillation counting of ${ }^{99} \mathrm{Tc}(0.292 \mathrm{MeV}$ $\beta$ ) (11). Briefly, in an anaerobic glovebox, the filtered $(0.2$ $\mu \mathrm{m})$ sample was added to tetraphenyl arsonium chloride (26) to obtain a TPAC:Tc molar ratio of 40:1. Samples were removed from the glovebox, weighed, and extracted with chloroform. The resulting chloroform layer was removed, and the concentration of Tc was determined by liquid scintillation counting. Lactate, fumarate, and succinate were quantified by capillary electrophoresisusinga Waters Quanta $4000 \mathrm{E}$ instrument and direct detection at $185 \mathrm{~nm}$. Run buffer was $25 \mathrm{mM} \mathrm{Na}_{2} \mathrm{~B}_{4} \mathrm{O}_{7}, 0.6 \mathrm{mM} \mathrm{CaCl}$, and $0.5 \mathrm{mM}$ tetradecyltrimethylammonium hydroxide (TTAOH), pH 9.2. Capillary: $75 \mu \mathrm{m}$ i.d. $\times 55 \mathrm{~cm}$ to the detector ( $62 \mathrm{~cm}$ total length). Separation conditions: $25^{\circ} \mathrm{C},-15 \mathrm{kV}$ constant voltage.

XAFS Analysis. Fluorescence XAFS measurements of the base solution $\left(50 \mu \mathrm{M} \mathrm{U}, 5 \mathrm{mM} \mathrm{CaCl}_{2}\right.$, and $30 \mathrm{mM} \mathrm{HCO}_{3}$ under anaerobic conditions with a $80: 20 \mathrm{~N}_{2}: \mathrm{CO}_{2}$ ratio headspace) at the $U \mathrm{~L}_{3}$ absorption edge (17166 eV) were performed at the Materials Research CollaborativeAccess Team (MR-CAT) (27) beamline 10-ID at the Advanced Photon Source at Argonne National Laboratory. Beamline parameters were as follows: IncidentX-ray energy was selected by usinga doublecrystal Si(111) monochromator. The third harmonic of the undulator was tapered $3.5 \mathrm{keV}$ to reduce the variation of the incident intensity to less than $20 \%$ over the scanned energy range ( $1000 \mathrm{eV})$. A Rh mirror rejected X-rays of higher harmonic energies. Incident X-ray intensity was monitored with a $\mathrm{N}_{2}$-filled ion chamber. Fluorescent X-rayintensity was monitored with a 13-element solid-state detector (Canberra with X1A electronics). EXAFS data were analyzed with the codes contained in the UWXAFS package (28) and IFEFFIT (29). Data collected from 11 elements of the solid-state detector for each energy scan were averaged to produce 10 absorption spectra. Background was removed from each of these data sets with the ATHENA program (30), and the resulting $\chi(\mathrm{k})$ data were averaged. Theoretical models were constructed with the program FEFF7 (31) and crystallographic atomic positions of andersonite (32). Models were fit to the data by using the fitting routine FEFFIT (33), which also performs error analysis and calculates the goodness-of-fit parameters. Details on the fitting procedure have been described previously for similar systems $(34,35)$.

\section{Results}

AqueousSpeciation of $\mathbf{U}(\mathbf{V})$ in Initial Solutions. Equilibrium Calculations. The rate and extent of $U(\mathrm{VI})$ removal from solution by the various DMRB was monitored as a function of calcium concentration. The $U$ aqueous species distribution in the various solutions prior to bacterial reduction was calculated using the React module in the commercially available software program The Geochemists Workbench (36). Formation constants for the $\mathrm{U}(\mathrm{VI})$ complexes were obtained from the extensive compilation of Grenthe et al. (37). Formation constants for uranium(VI) acetatecomplexes and $\mathrm{Ca}-\mathrm{UO}_{2}-\mathrm{CO}_{3}$ complexes were from Shock and Koretsky (38) and Bernhard et al. (23), respectively. In the absence of $\mathrm{Ca}, \mathrm{UO}_{2}\left(\mathrm{CO}_{3}\right)_{3}{ }^{4-}$ and $\mathrm{UO}_{2}\left(\mathrm{CO}_{3}\right)_{2}{ }^{2-}$ are predicted as the dominant aqueous species but decrease in abundance as the concentration of $\mathrm{Ca}$ in solution increases with a concomitant increase in $\mathrm{Ca}_{2} \mathrm{UO}_{2}\left(\mathrm{CO}_{3}\right)_{3}$ (Table 1). The predicted percent distribution of aqueous $\mathrm{U}(\mathrm{VI})$ species is invariant as the $\mathrm{U}(\mathrm{VI})$ concentration is decreased.

XAFSM easurements. The average $\chi(\mathrm{k}) \mathrm{k}$ data are shown in Figure 1a. The magnitude of the Fourier transform (FT) of 

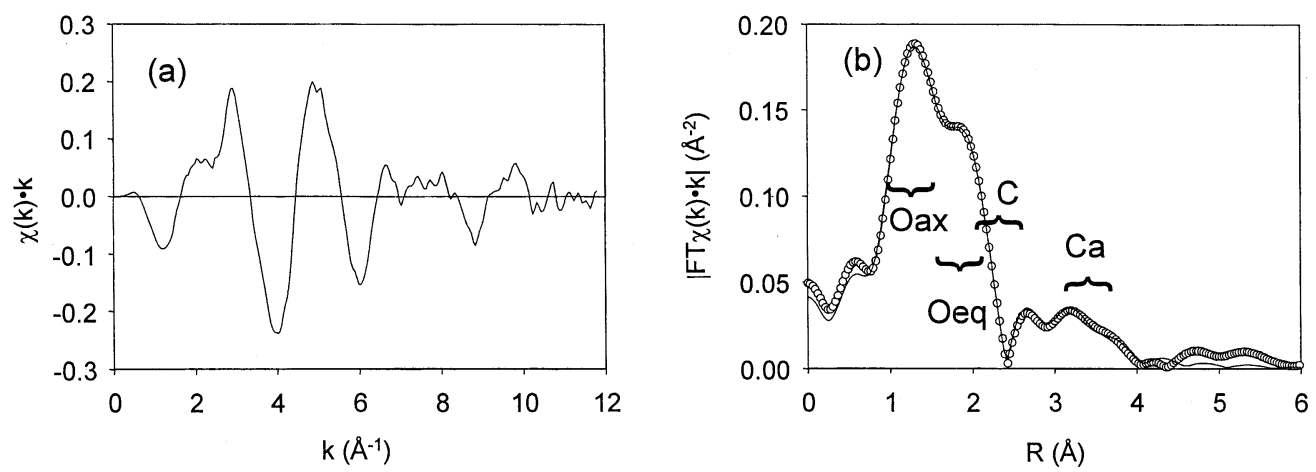

FIGURE 1. (a) XAFS $\chi(k) \cdot k$ data for Ca-containing base solution. (b) Magnitude of the Fourier transform of the data show $n$ in panel a (open circles) and best-fit model (thick line). Data processed with $\Delta k=3.3-9.3 \AA^{-1}, \Delta R=0.9-4.0 \AA$, and a Hanning window with a full sill width of $1.0 \AA^{-1}, 0_{a x}$, axial oxygen; $0_{\text {eq, }}$ equatorial oxygen.

TABLE 1. U(V) and Calcium Aqueous Species Distribution for the Conditions in These Experiments ${ }^{\mathrm{a}}$

\begin{tabular}{|c|c|c|c|c|}
\hline aqueous species & no Ca & $0.45 \mathrm{mM} \mathrm{Ca}$ & $2.5 \mathrm{mM} \mathrm{Ca}$ & $5.0 \mathrm{mM} \mathrm{C}$ \\
\hline \multicolumn{5}{|c|}{ Mol \% Total U(VI) } \\
\hline $\mathrm{UO}_{2}\left(\mathrm{CO}_{3}\right)_{3}^{4-}$ & 76.8 & 34.4 & 2.2 & 0.7 \\
\hline $\mathrm{UO}_{2}\left(\mathrm{CO}_{3}\right)_{2}{ }^{2-}$ & 23.1 & 10.2 & 0.6 & 0.2 \\
\hline $\mathrm{Ca}_{2} \mathrm{UO}_{2}\left(\mathrm{CO}_{3}\right)_{3}$ & & 51.0 & 95.8 & 98.4 \\
\hline $\mathrm{CaUO}_{2}\left(\mathrm{CO}_{3}\right)_{3}^{2-}$ & & 4.3 & 1.4 & 0.8 \\
\hline \multicolumn{5}{|c|}{ Mol \% Total Ca } \\
\hline $\mathrm{Ca}^{2+}$ & & 71.0 & 77.7 & 80.0 \\
\hline $\mathrm{CaHCO}_{3}{ }^{+}$ & & 11.9 & 12.5 & 12.3 \\
\hline calcium lactate ${ }^{+}$ & & 4.7 & 4.9 & 4.8 \\
\hline $\mathrm{CaCO}_{3, \mathrm{aq}}$ & & 0.7 & 0.7 & 0.7 \\
\hline $\mathrm{Ca}_{2} \mathrm{UO}_{2}\left(\mathrm{CO}_{3}\right)_{3}$ & & 11.3 & 3.8 & 2.0 \\
\hline $\mathrm{CaUO}_{2}\left(\mathrm{CO}_{3}\right)_{3}^{2-}$ & & 0.5 & 0.03 & \\
\hline
\end{tabular}

a Base medium consisted of $30 \mathrm{mM} \mathrm{NaHCO}, 5 \mathrm{mM}$ sodium lactate, $50 \mu \mathrm{M} \mathrm{\cup O}$ (acetate) $)_{2}$, and $20 \% \mathrm{CO}_{2}$ at $\mathrm{pH} 6.9$.

TABLE 2. Best-Fit Values for XAFS Model of Ca-Containing Base Solutiona

\begin{tabular}{|c|c|c|c|c|}
\hline scattering path ${ }^{b}$ & $N_{\text {degen }}^{c}$ & $R(\mathbf{A})^{d}$ & $\begin{array}{c}\sigma^{2} \\
\left(10^{-3} \AA^{2}\right)^{e}\end{array}$ & $\Delta E_{0}(\mathrm{eV})^{f}$ \\
\hline $\begin{array}{l}U-O_{a x} \\
U-O_{e q} \\
U-C \\
U-O_{a \times 1}-O_{a \times 2} \\
U-O_{a \times 1}-U-O_{a \times 1} \\
U-O_{a \times 1}-U-O_{a \times 2} \\
U-C a\end{array}$ & $\begin{array}{l}2 \\
5.5 \pm 0.7^{g} \\
2.7 \pm 0.4^{g} \\
2 \\
2 \\
2 \\
3.4 \pm 0.9\end{array}$ & $\begin{array}{l}1.78 \\
2.45 \pm 0.01 \\
2.90 \\
3.56 \\
3.56 \\
3.56 \\
4.01+0.01\end{array}$ & $\begin{array}{l}1 \pm 1 \\
6 \pm 2 \\
4 \pm 2 \\
2 \pm 2 \\
2 \pm 2 \\
2 \pm 2 \\
6 \pm 3\end{array}$ & $\begin{array}{l}0.2 \pm 0.5 \\
6.8 \pm 1.0 \\
6.8 \pm 1.0 \\
0.2 \pm 0.5 \\
0.2 \pm 0.5 \\
0.2 \pm 0.5 \\
6.8 \pm 1.0\end{array}$ \\
\hline
\end{tabular}

${ }^{a}$ Values without uncertainties were constrained to the value listed. ${ }^{b}$ Scattering path of the photoelectron. Single scattering paths are denoted $U-X$ where $X$ is the type of atoms in a shell about the uranium atoms. $\mathrm{O}_{a x}$, axial oxygen; $\mathrm{O}_{\mathrm{eq}}$, equatorial oxygen. ' ${ }^{\mathrm{D}}$ Degeneracy of the photoelectron scattering path. For a single scattering path, this is the number of atoms in a shell about the uranium atoms. ${ }^{d}$ The half path length of the photoelectron scattering path. For a single scattering path, this is the distance from the uranium atoms to a shell of atoms. e Meansquare displacement of $R(\AA)$. For a singlescattering path, this represents the amount of structural and thermal disorder in the shell of atoms about the uranium atoms in the sample. ${ }^{f}$ Energy shift of the photoelectron scattering path. ${ }^{g}$ Number of $\mathrm{O}_{\mathrm{eg}}$ and $\mathrm{C}$ atoms were determined based on a single variable for the number of $\mathrm{CO}_{3}$ groups.

the EXAFS data and model are shown in Figure 1b. Contributions to XAFS signal used to model these data include (i) two tightly bound axial oxygen atoms, (ii) six equatorial oxygen atoms, (iii) three carbon atoms (which are part of the $\mathrm{CO}_{3}$ groups bound to the uranyl moiety), and (iv) three calcium atoms (bound to the carbonates). Additional details for this model are contained in Table 2. Results of the fitting of the $\mathrm{k}$ dependence of the backscattering amplitudes in the region of $\sim 4 \AA$ in the FT are consistent with the presence of a Ca backscattering atom and are not consistent with a $\mathrm{C}$ or $\mathrm{O}$ backscattering atom. Therefore, the contribution of multiple scattering processes to the distal $\mathrm{O}$ atoms of the carbonate groups are not included in our fits, as described in a previous study (23). The number of atoms in each coordination shell, their distance to the absorbing uranium atom, and their mean-squaredisplacement values aresimilar to those found for other uranyl coordination environments $(23,34,39)$. Results of this fitting are in good agreement with the XAFS data and consistent with the formation of a Ca$\mathrm{UO}_{2}-\mathrm{CO}_{3}$ complex, thus confirming the presence of thistype of moiety in the base solutions.

U(V) Reduction byS. putrefaciens CN32. U ranyl (U(VI)) reduction by aerobically cultured S. putrefaciensCN 32 (CN32) with lactate as electron donor proceeded rapidly with complete reduction within $30 \mathrm{~h}$ (Figure 2a). There was no lag phase prior to $\mathrm{U}(\mathrm{VI})$ reduction for this treatment. Theaddition of $0.45 \mathrm{mM}$ Ca to the medium resulted in a 5 -h lag phase and a marked decrease in the rate and extent of $U$ reduction with only $\sim 75 \%$ of the initial $\mathrm{U}(\mathrm{VI})$ reduced after $97 \mathrm{~h}$. Further increasing the concentration of Ca to $2.5 \mathrm{mM}$ extended the lag phase to $60 \mathrm{~h}$ before the onset of $U$ reduction. Reduction of $\mathrm{U}(\mathrm{VI})$ proceeded much more slowly once initiated, and only $70 \%$ of $\mathrm{U}(\mathrm{VI})$ was reduced after about 6 days with little or no additional reduction over the ensuing 4 days even though excess lactate $(>4 \mathrm{mM}$ ) remained in solution (Figure 2a).

Possible causes for the inhibition of $U(\mathrm{VI})$ reduction in the presence of Ca include (i) the complexation of lactate by Ca making it less bioavailable as an electron donor, (ii) a direct physiological effect of $\mathrm{Ca}$ on the cells that inhibited $\mathrm{U}(\mathrm{VI})$ reduction, or (iii) the formation of an aqueous $\mathrm{Ca}-$ $\mathrm{U}-\mathrm{CO}_{3}$ complex that was less susceptible to enzymatic reduction by $\mathrm{CN} 32$. Theexperiments described below address each of these possible causes.

Equilibrium speciation calculations indicated that 95\% of the lactateremained as free lactate with $2.5 \mathrm{mM}$ Ca present, suggesting that formation of calcium lactate complexes was not the reason for the observed effect. Nevertheless, this possible cause was evaluated directly in reduction experiments using anaerobically grown (with fumarate) CN32 cells using $\mathrm{H}_{2}$ as the electron donor. The rate of $\mathrm{U}$ reduction with $\mathrm{H}_{2}$ as electron donor was comparable to that observed for lactate in the absence of $\mathrm{Ca}$ (Figure 2b). There was no lag phase, and $\mathrm{U}(\mathrm{VI})$ reduction was complete within $13 \mathrm{~h}$. These results are consistent with an earlier report that $\mathrm{H}_{2}$ supports a comparable but slightly faster rate of $\mathrm{U}(\mathrm{VI})$ reduction by CN32 (40). The addition of $0.45 \mathrm{mM} \mathrm{Ca}\left(\mathrm{as} \mathrm{CaCl}_{2}\right.$ ) to the medium resulted in a decrease in the rate of $U$ reduction. When the concentration of Ca was $5 \mathrm{mM}$, there was a substantial lag phase prior to the onset of $U$ reduction. Only $37 \%$ of $U$ was reduced after $72 \mathrm{~h}$ with no additional $U(\mathrm{VI})$ loss 

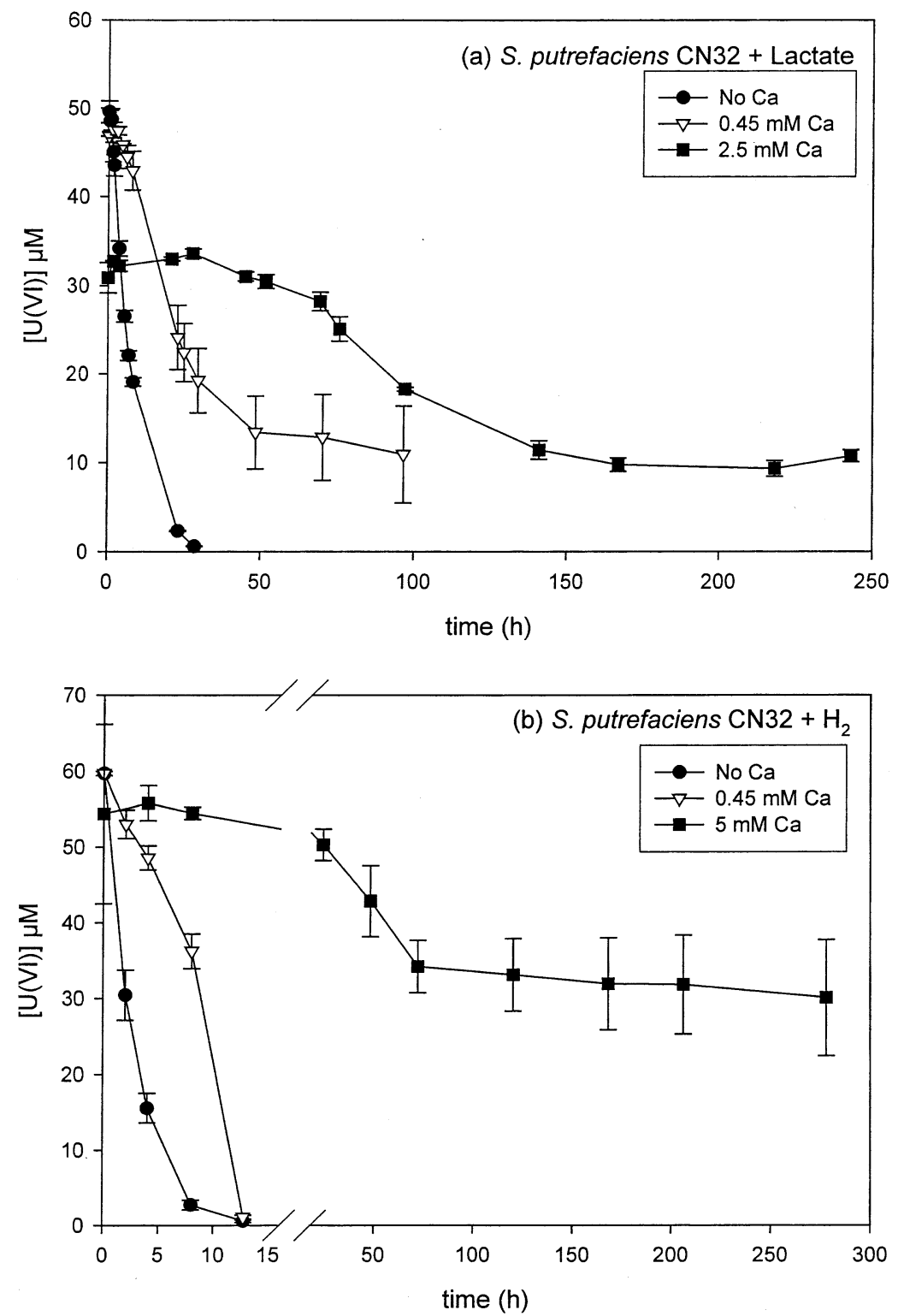

FIGURE 2. Removal of U(VI) from solution by S. putrefaciens strain CN 32 at varying concentrations of Ca using either (a) aerobically cultured cells and lactate as electron donor or (b) anaerobically cultured cells and $\mathrm{H}_{2}$ as electron donor.

over the ensuing 8.6 days (Figure $2 b$ ). Thus, the inhibition caused by $\mathrm{Ca}$ was independent of the electron donor, suggesting either specific Ca-cell or $\mathrm{Ca}-\mathrm{U}$ interactions as the cause of the observed effect.

An alternate electron acceptor, fumarate, was selected to investigate whether exposureto the $\mathrm{Ca}-\mathrm{U}(\mathrm{VI})-\mathrm{CO}_{3} \mathrm{Complex}$ or the length of experiments adversely impacted CN32. The reduction potential of thefumarate $\rightarrow$ succinatecoupleunder the experimental conditions is similar to that of the uranyl carbonate species (Table 3). A U (VI) reduction experiment was conducted as before except the final cell concentration was $\sim 5 \times 10^{7}$ cells $/ \mathrm{mL}$ as compared to $\sim 10^{8}$ cells $/ \mathrm{mL}$ in other experiments. The effect of $\mathrm{Ca}$ on $\mathrm{U}(\mathrm{VI})$ reduction was comparable to that observed previously (Figure 3). On the sixth day, fumarate from a concentrated stock solution was added to the reaction vessels to achieve an initial concentration of $\sim 500 \mu \mathrm{M}$. The dilution effect from addingthefumarate was less than $3 \%$. The loss of fumarate and stoichiometric production of succinate was monitored over time. Fumarate consumption proceeded rapidly with greater than $95 \%$ loss in less than $2 \mathrm{~h}$, regardless of the presence of $\mathrm{Ca}$ (Figure 3). The results of this experiment suggest that neither length of the incubations nor exposure to the $\mathrm{Ca}-\mathrm{U}(\mathrm{VI})-\mathrm{CO}_{3}$ complex negatively impacted the ability of $\mathrm{CN} 32$ to reduce fumarate.

Another alternate electron acceptor, Tc(VII), was chosen to investigate whether $\mathrm{Ca}$-cell interactions or $\mathrm{Ca}$ effects on organism physiology may be responsible for a general inhibition of metal reduction. The loss of Tc from solution was monitored in suspensions of CN32 using either $5 \mathrm{mM}$ sodium lactate or $2.5 \mathrm{mM} \mathrm{Ca(lactate})_{2}$ as electron donor. The presence of $\mathrm{Ca}$ in the medium did not inhibit the loss of Tc from solution (Figure 4). In fact, $\mathrm{Tc}(\mathrm{VII})(\mathrm{aq})$ loss proceeded more rapidly in the presence of $2.5 \mathrm{mM} \mathrm{Ca}$, although additional experiments are needed to establish whether this effect is significant. Nevertheless, the results of this experiment suggest that Ca per se does not have a direct physiological effect on cells of strain CN32. In addition, these results lend further support to the previous results showing that formation of calcium lactate complexes did not inhibit metal reduction.

Similar to the results reported for Tc, Zhang et al. (41) reported rapid $U(\mathrm{VI})$ reduction with no evidence of a lag phase by another metal-reducing Shewanella strain, S. algae $\mathrm{BrY}$, using $\mathrm{H}_{2}$ as an electron donor in carbonate free medium 
TABLE 3. Half-Cell Potentials of Aqueous U(V) Species and Electron Donors Used in the Experiments

$$
E^{\circ}(\mathrm{V})
$$

$E(V){ }^{a}$

(1)

(2)

(3)

(4)

(5)

(6)

(7)

(8)

$$
\begin{aligned}
& \mathrm{UO}_{2}^{2+}+2 \mathrm{e}^{-} \rightarrow \quad \mathrm{UO}_{2, \mathrm{cr}} \\
& \text { (uraninite) } \\
& \mathrm{UO}_{2}\left(\mathrm{CO}_{3}\right)_{3} 3^{4-}+3 \mathrm{H}^{+}+2 \mathrm{e}^{-} \rightarrow \mathrm{UO}_{2, \mathrm{cr}}+3 \mathrm{HCO}_{3}^{-} \\
& \mathrm{UO}_{2}\left(\mathrm{CO}_{3}\right)_{2}^{2-}+2 \mathrm{H}^{+}+2 \mathrm{e}^{-} \rightarrow \mathrm{UO}_{2, \mathrm{cr}}+2 \mathrm{HCO}_{3}^{-} \\
& \mathrm{Ca}_{2} \mathrm{UO}_{2}\left(\mathrm{CO}_{3}\right)_{3, \mathrm{aq}}+3 \mathrm{H}^{+}+2 \mathrm{e}^{-} \rightarrow \mathrm{UO}_{2, \mathrm{cr}}+2 \mathrm{Ca}^{2+}+3 \mathrm{HCO}_{3}^{-} \\
& \mathrm{CaUO}_{2}\left(\mathrm{CO}_{3}\right)_{3}{ }^{2-}+3 \mathrm{H}^{+}+2 \mathrm{e}^{-} \rightarrow \mathrm{UO}_{2, \mathrm{cr}}+\mathrm{Ca}^{2+}+3 \mathrm{HCO}_{3}^{-} \\
& \mathrm{C}_{4} \mathrm{H}_{4} \mathrm{O}_{4}{ }^{2-}+2 \mathrm{H}^{+}+2 \mathrm{e}^{-} \rightarrow \mathrm{C}_{4} \mathrm{H}_{4} \mathrm{O}_{4}{ }^{2-} \\
& \text { (fumarate) (succinate) } \\
& 2 / 3 \mathrm{TCO}_{4}^{-}+2 \mathrm{e}^{-}+8 / 3 \mathrm{H}^{+} \rightarrow 2 / 3 \mathrm{TCO}_{2}+4 / 3 \mathrm{H}_{2} \mathrm{O} \\
& \text { Electron Donor } \\
& \mathrm{H}^{+}+\mathrm{e}^{-} \rightarrow 1 / 2 \mathrm{H}_{2}(\mathrm{~g}) \\
& 2 \mathrm{HCO}_{3}{ }^{-}+9 \mathrm{H}^{+}+8 \mathrm{e}^{-} \rightarrow \mathrm{CH}_{3} \mathrm{COO}^{-}+4 \mathrm{H}_{2} \mathrm{O} \\
& \text { (acetate) } \\
& 3 \mathrm{HCO}_{3}^{-}+14 \mathrm{H}^{+}+12 \mathrm{e}^{-} \rightarrow \mathrm{C}_{3} \mathrm{H}_{5} \mathrm{O}_{3}^{-}+6 \mathrm{H}_{2} \mathrm{O} \\
& \text { (lactate) } \\
& \mathrm{CH}_{3} \mathrm{COO}^{-}+\mathrm{HCO}_{3}^{-}+4 \mathrm{e}^{-}+5 \mathrm{H}^{+} \rightarrow \mathrm{C}_{3} \mathrm{H}_{5} \mathrm{O}^{-}+2 \mathrm{H}_{2} \mathrm{O}
\end{aligned}
$$

$\begin{array}{lr}0.411 & 0.284^{b} \\ & \\ 0.689 & 0.086^{b} \\ 0.521 & 0.077^{b} \\ 0.424 & -0.042^{c} \\ 0.576 & 0.042^{c} \\ 0.407 & 0.079^{d} \\ & \\ 0.747 & 0.118^{e} \\ 0 & -0.408^{f} \\ 0.187 & -0.278^{g} \\ 0.156 & -0.332^{h} \\ 0.093 & -0.465^{i}\end{array}$

${ }^{a}$ Reduction potential under experimental conditions. ${ }^{b} \mathrm{pH} 6.9 ; \mathrm{HCO}_{3}{ }^{-}, 28.7 \mathrm{mM}$ (calculated concentration under the $20 \% \mathrm{CO}_{2}$ headspace); $\mathrm{U}(\mathrm{VI})$, $50 \mu \mathrm{M}$; Ca, $5 \mathrm{mM}$. ${ }^{C} \mathrm{HCO}_{3}{ }^{-}, 28.1 \mathrm{mM}$; Ca, $5 \mathrm{mM}$; other conditions as in footnote $b$. ${ }^{d}$ Fumarate, $0.5 \mathrm{mM}$; succinate, $0.001 \mathrm{mM}$. ${ }^{e} \mathrm{TCO}_{2}$, hydrous oxide based on observations of Wildung et al. (11); Tc data from Lemire and J obe (50). ${ }^{f} P_{\mathrm{H}_{2}(\mathrm{~g})}=1 \mathrm{~atm} .{ }^{g} \mathrm{pH} 6.9 ; \mathrm{HCO}_{3}{ }^{-}, 28.7 \mathrm{mM} ; \mathrm{CH}_{3} \mathrm{COO}^{-}, 5 \mathrm{mM} .{ }^{h} \mathrm{pH}$ $6.9 ; \mathrm{HCO}_{3}^{-}, 28.7 \mathrm{mM} ; \mathrm{C}_{3} \mathrm{H}_{5} \mathrm{O}_{3}{ }^{-}, 5 \mathrm{mM}$. ${ }^{i}$ S. putrefaciens $\mathrm{CN} 32$ incompletely oxidizes lactate to acetate and $\mathrm{CO}_{2} . \mathrm{pH}^{-} 6.9 ; \mathrm{HCO}_{3}^{-}, 28.7 \mathrm{mM}^{-} \mathrm{CH}_{3} \mathrm{COO}^{-}$, $0.1 \mathrm{mM}$ from $\mathrm{UO}_{2}$ (acetate) $)_{2}$ used as the source of $\mathrm{U}(\mathrm{VI}) ; \mathrm{C}_{3} \mathrm{H}_{5} \mathrm{O}_{3}{ }^{-}, 5 \mathrm{mM}$.

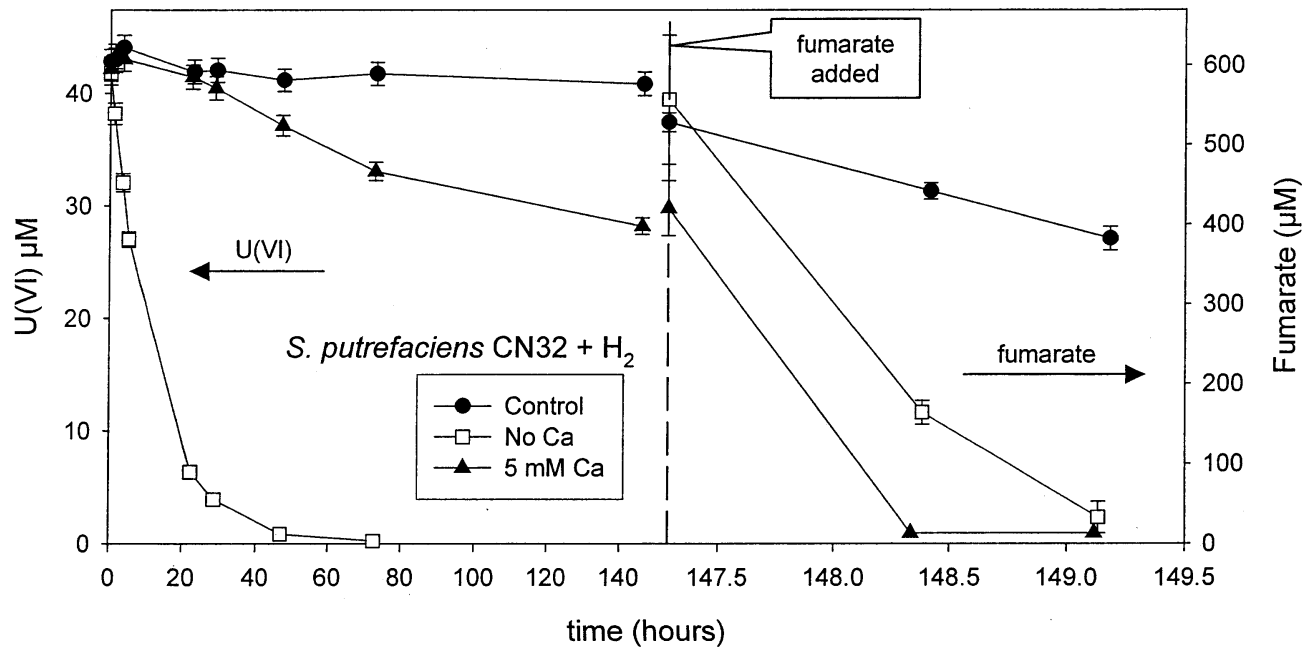

FIGURE 3. Reduction of U(VI) and fumarate by aerobically cultured cells of $S$. putrefaciens strain $\mathrm{CN} 32\left(\sim 5 \times 10^{7}\right.$ cells $\left./ \mathrm{mL}\right)$ using $\mathrm{H}_{2}$ as electron donor. Fumarate was added to media after 6-day incubation.

containing $5 \mathrm{mM} \mathrm{CaCl} 2$ at $\mathrm{pH}$ 7. These results suggest that a direct $\mathrm{Ca}$-cell interaction was not responsible for the observed inhibition of $U$ reduction, although, as noted in the Introduction, comparison between strains can be problematic. However, Ca may have an indirect effect on enzymatic reduction of $U$, possibly via the formation of a $\mathrm{Ca}_{2} \mathrm{UO}_{2}\left(\mathrm{CO}_{3}\right)_{3}$ aqueous complex that may be of lower biological availability.

U(V) Reduction by Obligate Anaerobic Bacteria. The results described above demonstratethat Ca inhibits the rate and extent of $\mathrm{U}(\mathrm{VI})$ reduction by $\mathrm{S}$. putrefaciens CN 32 in the presence of $\mathrm{CO}_{2} / \mathrm{HCO}_{3}$, putatively through the formation of a $\mathrm{Ca}-\mathrm{U}-\mathrm{CO}_{3}$ complex. Given the diversity of bacteria that can reduce $\mathrm{U}(\mathrm{VI})$, we sought to establish whether this effect was specific to the facultative anaerobe CN32 or was more generally applicableto other uranium-reducing bacteria. We thereforeinvestigated whether $\mathrm{U}(\mathrm{VI})$ reduction by theobligate anaerobes D. desulfuricans and G. sulfurreducens was inhibited by $\mathrm{Ca}$.
The loss of $\mathrm{U}(\mathrm{VI})$ from solution with $\mathrm{D}$. desulfuricanswas monitored over time in the absence and presence of $5 \mathrm{mM}$ $\mathrm{Ca}$. U(VI) loss from solution was rapid in the absence of $\mathrm{Ca}$ using either lactate or $\mathrm{H}_{2}$ as electron donor (Figure 5). Virtually all the $\mathrm{U}(\mathrm{VI})$ was removed from solution within 5 days. There was a marked decrease in the rate and extent of $U$ reduction when $5 \mathrm{mM}$ Ca was included in the medium, regardless of electron donor. Less than $20 \% \mathrm{U}(\mathrm{VI})$ was removed from solution over 5 days when Ca was present.

G. sulfurreducens reduced $35 \% \mathrm{U}(\mathrm{VI})$ within $48 \mathrm{~h}$ with 5 $\mathrm{mM}$ acetate as the electron donor in the absence of $\mathrm{Ca}$. No further reduction was observed over an additional 10 days of incubation (Figure 6). The low acetate control replicates shown in Figure 6 had $0.1 \mathrm{mM}$ acetate that was associated with the $\mathrm{UO}_{2}$ (acetate) ${ }_{2}$ used as the source of $\mathrm{U}(\mathrm{VI})$. Given the experimental variation, $\mathrm{U}(\mathrm{VI})$ reduction at the two concentrations of acetatewerenot significantly different. Incubations that included $5 \mathrm{mM}$ Ca showed no $\mathrm{U}(\mathrm{VI})$ loss over the first 5 days with less than $20 \%$ loss over the subsequent 7 days. 


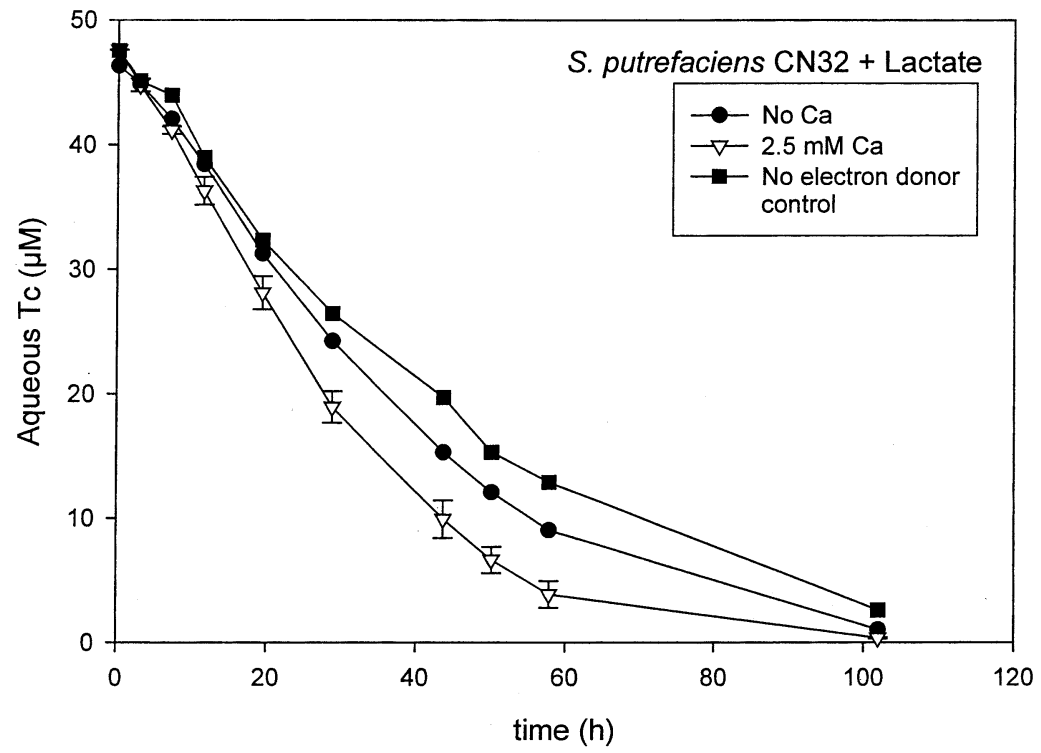

FIGURE 4. Removal of TC from solution by S. putrefaciens strain CN32 in the absence and presence of Ca. Loss of Tc in the control experiments is the result of endogenous respiration by fresh cultures of CN32 grow $n$ in TSB.

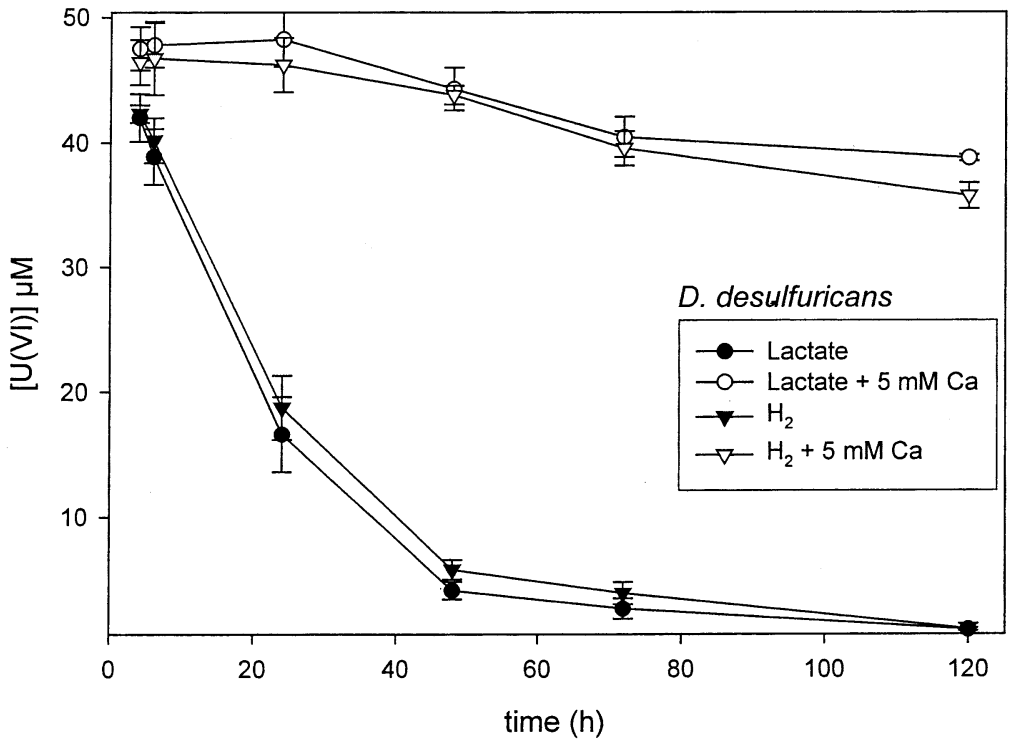

FIGURE 5. $\mathrm{U}(\mathrm{VI})$ reduction in bicarbonate-buffered medium by $\mathrm{D}$. desulfuricans using either lactate or $\mathrm{H}_{2}$ as electron donor.

The reason for the relatively poor reduction of $U$ by $G$. sulfurreducens in the absence of $\mathrm{Ca}$ is unclear, although the initial report describing theisolation and characterization of strain PCA indicated that it was unable to utilize $\mathrm{U}(\mathrm{VI})$ or $\mathrm{Mn}(\mathrm{IV})$ as electron acceptors (42).

Various media have been used in batch metal reduction experiments reported in the literature. In some cases, trace metals or vitamins are added to the solution to enhance cell maintenance and/ or growth $(16,43)$. Including these amendmentsin the medium may complicateinterpretation of results as the trace metal and vitamin solutions both contain redox active components that can potentially act as electronshuttling compounds promoting the reduction of theelectron acceptors of interest. For example, the DMRB S. al gaestrain $\mathrm{BrY}$ cannot effectively reduce carbon tetrachloride $\left(\mathrm{CCl}_{4}\right)$ or chloroform (CF) via direct mechanisms. BrY does, however, reduce vitamin $\mathrm{B}_{12}$ that can subsequently reduce $\mathrm{CCl}_{4}$ and CF (44).

The effect of trace mineral and vitamin amendments on $U$ reduction was tested in a series of experiments with $\mathrm{CN} 32$ using lactate as electron donor and $2.5 \mathrm{mM} \mathrm{Ca}$. Trace mineral and vitamin solutions were the same as described by other investigators $(16,25,45)$. The trace minerals solution contains NTA (final concentration, $0.0785 \mathrm{mM}$ ) that could alter $U$ species distribution either directly through formation of $\mathrm{U}$-NTA complexes or indirectly via complexation of Ca. Results of equilibrium speciation modeling indicated that the predicted initial concentration and distribution of $U$ species was not affected by the trace minerals solution. Including trace minerals in the bicarbonate-buffered solution resulted in a substantially faster loss of $\mathrm{U}(\mathrm{VI})$ from solution (Figure 7). Nevertheless, there was still a lag phase (11 h) prior to the onset of $U$ reduction, and reduction was incomplete (96\%). There was no lag in reduction when trace vitamins were included in thesolution, and therate of $U$ loss was comparable to when Ca was absent. However, U loss ceased after the removal of $84 \% \mathrm{U}(\mathrm{VI})$. The addition of trace minerals and vitamins together also enhanced the rate of $U$ loss from solution. There was still a notable lag phase $(23 \mathrm{~h})$, and $U$ reduction was again incomplete (97\%) after 6 days. The addition of both amendments yielded slower $U$ loss relative to the addition of either thetracemineralsor vitamins 


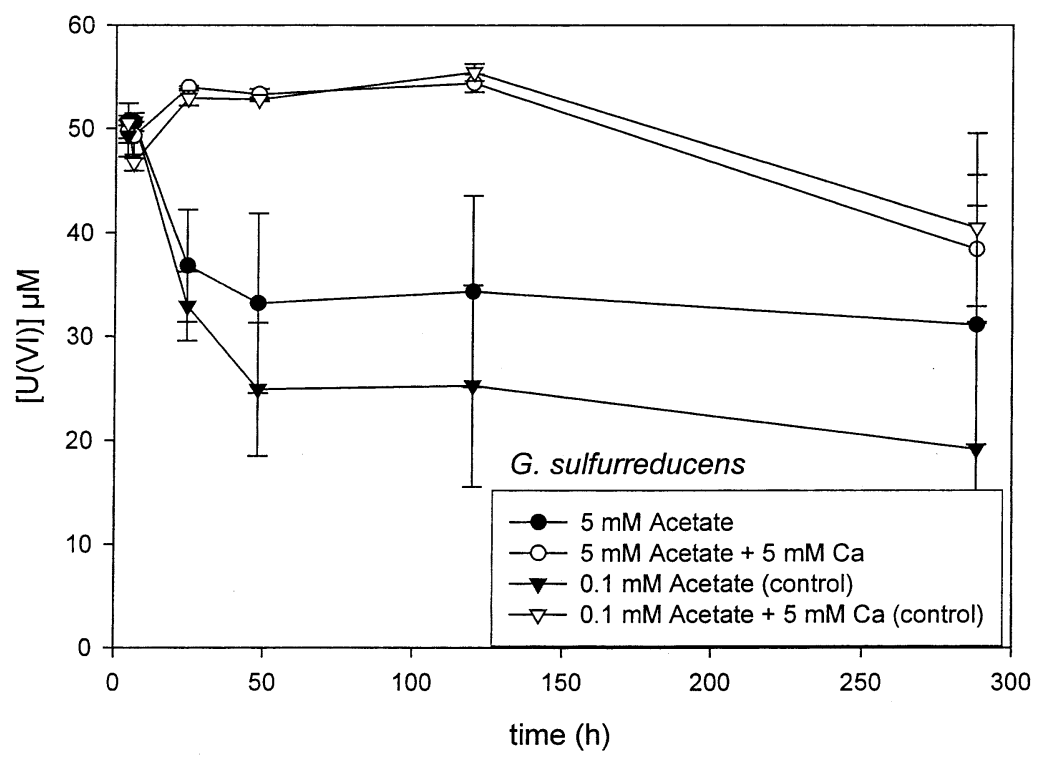

FIGURE 6. U(VI) reduction in bicarbonate-buffered medium by Geobacter sulfurreducens using acetate as electron donor.

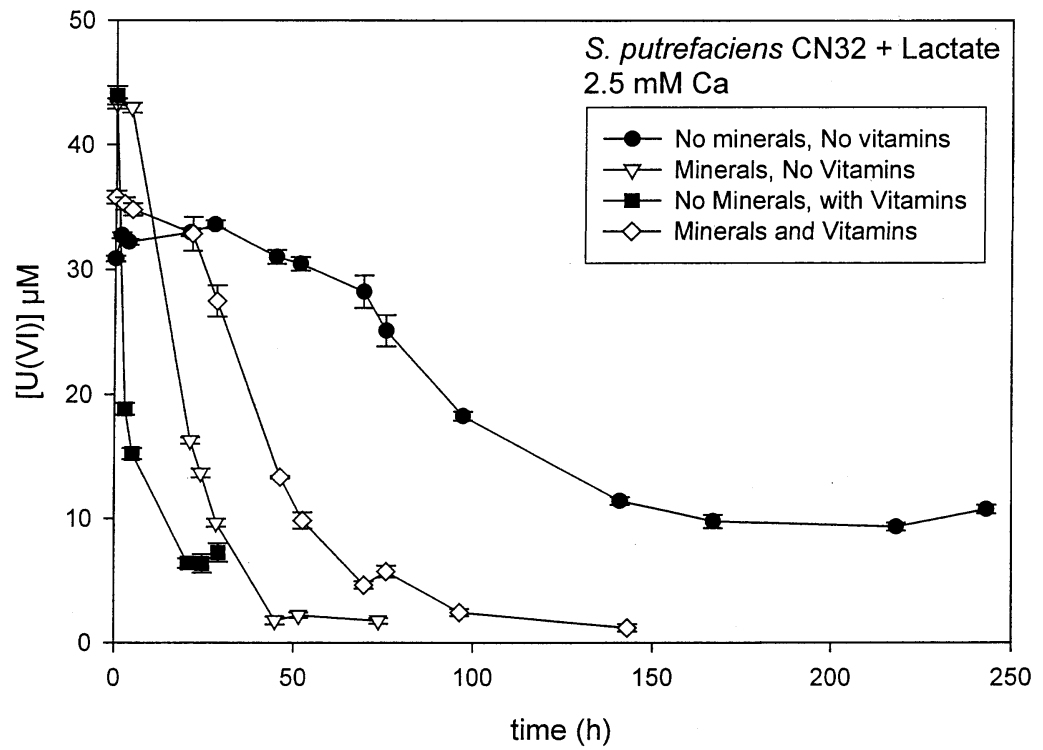

FIGURE 7. Effect of trace minerals and vitamins on U(VI) removal from solution by S. putrefaciens strain CN32 from bicarbonate-buffered medium with $2.5 \mathrm{mM} \mathrm{Ca}$ and lactate as electron donor.

separately. We observed no increase in cell numbers over the course of these experiments, although these amendments may have promoted metabolic reactions that promoted $\mathrm{U}(\mathrm{VI})$ reduction. Alternately, these results may be due to indirect effects such as el ectron shuttling by components of thetrace minerals or vitamins solution.

Calcium, at millimolar concentrations, caused a significant decrease in the rate and extent of bacterial $\mathrm{U}(\mathrm{VI})$ reduction. Both facultative and obligate anaerobic U-reducing bacteria were affected by the presence of calcium. The results are consistent with the hypothesis that $U$ is a less effective electron acceptor when the $\mathrm{Ca}_{2} \mathrm{UO}_{2}\left(\mathrm{CO}_{3}\right)_{3}$ complex is present. The results do not support $\mathrm{Ca}$ inhibition caused by direct interactions with the cells or with the electron donor.

Complexation of uranium stabilizes the higher oxidation state, lowering the reduction potential of the $\mathrm{U}(\mathrm{VI}) \rightarrow \mathrm{UO}_{2, \mathrm{cr}}$ couple. Equilibrium thermodynamic calculations indicate that $\mathrm{Ca}_{2} \mathrm{UO}_{2}\left(\mathrm{CO}_{3}\right)_{3}$ is a weaker electron acceptor than the other $\mathrm{U}(\mathrm{VI})$ forms predicted to exist in the experiments with a reduction potential morethan $0.1 \mathrm{~V}$ lower than $\mathrm{UO}_{2}\left(\mathrm{CO}_{3}\right)_{3}{ }^{4-}$ (Table 3). Using the $\mathrm{Ca}_{2} \mathrm{UO}_{2}\left(\mathrm{CO}_{3}\right)_{3} \rightarrow \mathrm{UO}_{2, \text { cr }}$ couple, the final
TABLE 4. Computed Final $\mathrm{E}_{\mathrm{h}}$ Based on the $\mathrm{Ca}_{2} \mathrm{UO}_{2}\left(\mathrm{CO}_{3}\right)_{3} \rightarrow$ $\mathrm{UO}_{2, \text { cr }}$ Couple for Experiments Containing $5 \mathrm{mM} \mathrm{Ca}$

\begin{tabular}{llcc}
\multicolumn{1}{c}{ organism } & \multicolumn{1}{c}{$\mathbf{e}^{-}$donor } & $\mathbf{E}_{\mathbf{h}}(\mathbf{V})$ & Figure \\
S. putrefaciens CN32 & $\mathrm{H}_{2}$ & -0.048 & $2 \mathrm{~b}$ \\
D. desulfuricans & lactate & -0.045 & 5 \\
D. desulfuricans & $\mathrm{H}_{2}$ & -0.046 & 5 \\
G. sulfurreducens & acetate $(5 \mathrm{mM})$ & -0.045 & 6 \\
G. sulfurreducens & acetate $(0.1 \mathrm{mM})$ & -0.044 & 6 \\
& average $\pm \mathrm{SD}$ & $-0.046 \pm 0.001$
\end{tabular}

system $E_{h}$ was calculated for the experiments with $5 \mathrm{mM} \mathrm{Ca}$. U ranium $(\mathrm{VI})$ reduction ceased when the system $\mathrm{E}_{\mathrm{h}}$ reached $-0.046 \mathrm{~V}$ (Table 4). Thus, the observed plateau in $\mathrm{U}(\mathrm{VI})$ reduction in the presence of $5 \mathrm{mM}$ Ca may represent a fundamental limit on the extent of direct bacterial $\mathrm{U}(\mathrm{VI})$ reduction that can be effected by the terminal reductase enzymes and their measured or theoretical midpoint potentials in these bacterial strains. At present, the enzymes responsible for $\mathrm{U}$ reduction in these organisms are not wellcharacterized so it is not possible to directly compare the 
calculated system $E_{h}$ with the enzyme reduction potentials. However, cytochromes with low midpoint potentials have been described for S. putrefaciens $(-0.233 \mathrm{~V} ; 46)$, D. de sulfuricans ( -0.165 to $-0.4 \mathrm{~V} ; 47)$, and $\mathrm{G}$. sulfurreducens $(-0.167 \mathrm{~V} ; 48)$. It is not known if these cytochromes are involved in the direct reduction of $\mathrm{U}(\mathrm{VI})$ by these bacteria.

The uranium reduction potentials described above indicate the sequence in which $\mathrm{U}(\mathrm{VI})$ species will be used according to their thermodynamic possibility, but they do not make a prediction about the rate of reaction. Nor do the reduction potentials account for the lag phase observed. Even at the highest calcium concentrations tested, some $\mathrm{U}(\mathrm{VI})$ remains as $\mathrm{UO}_{2}\left(\mathrm{CO}_{3}\right)_{3}{ }^{4-}$ and $\mathrm{UO}_{2}\left(\mathrm{CO}_{3}\right)_{2}{ }^{2-}$ complexes (Table 1 ), which should be available for reduction by the bacteria. Asthese species are consumed, the system will reequilibrate, maintaining a pool of these species in solution. The slow rate of reduction in the presence of calcium may reflect a kinetically slow reequilibration of the aqueous $\mathrm{U}(\mathrm{VI})$ complexes representing therate-determining step in theremoval of $\mathrm{U}(\mathrm{VI})$ in these systems. Alternately, the $\mathrm{Ca}_{2} \mathrm{UO}_{2}\left(\mathrm{CO}_{3}\right)_{3}$ complex may act as a competitive inhibitor of the reduction other $\mathrm{U}(\mathrm{VI})$ species (e.g., $\mathrm{UO}_{2}\left(\mathrm{CO}_{3}\right)_{3}{ }^{4-}$ ) that is either reduced more slowly or not at all.

Calcium and dissolved $\mathrm{CO}_{2}$ are ubiquitous components of natural and contaminated groundwater. In addition, the alkaline leaching of some $U$ ores has introduced significant amounts of $\mathrm{HCO}_{3}{ }^{-}$into impacted groundwater (49). At the Field Research Center for the U.S. Department of Energy's Natural and Accelerated Bioremediation Research (NABIR) program located on the Oak Ridge sitein eastern Tennessee, groundwater has been contaminated with uranium-bearing nitric acid wastes that percolated through carbonate host rock. The resulting calcium concentrations at the site range from 1 to $300 \mathrm{mM}$, and carbonate alkalinity ranges from 1 to $10 \mathrm{mM}$ (http:// public.ornl.gov/ nabirfrc/ dataarea123.cfm; accessed August 6, 2002). Similar concentrations of $\mathrm{Ca}$ and alkalinities arefound at U ranium Mill Tailing Remedial Action (UMTRA) sites (20). The dominant U (VI) species in seepage water from $\mathrm{U}$ minetailings in Germany is $\mathrm{Ca}_{2} \mathrm{UO}_{2}\left(\mathrm{CO}_{3}\right)_{3}(21)$. Bacterially mediated $\mathrm{U}(\mathrm{VI})$ reduction is being explored or tested at both the NABIR site and UMTRA sites for thein situ removal of uranium from groundwater. Results of this research indicate that the inorganic $\mathrm{Ca}_{2} \mathrm{UO}_{2}\left(\mathrm{CO}_{3}\right)_{3}$ complex may pose a fundamental limit for enzymatic reduction by DMRB that must be addressed prior to the successful application of bacterial $\mathrm{U}(\mathrm{VI})$ reduction for the purpose of groundwater cleanup.

\section{Acknowledgments}

This research was funded by theU .S. Department of Energy's Office of Science Biological and Environmental Research, Natural and Accelerated Bioremediation Research (NABIR) program. Oak Ridge National Laboratory is managed by UTBattelle, LLC, for the U.S. Department of Energy under Contract DE-AC05-000R22725. Pacific Northwest National Laboratory is operated for the DOE by Battelle Memorial Institute under Contract DE-AC06-76RLO 1830. The Advanced Photon Source is supported by the U.S. Department of Energy, Office of Science, Office of Basic Energy Sciences. Work performed at MRCAT (beamline 10-ID) is supported, in part, by funding from the Department of Energy (Grant DEFG0200ER45811). WethankE. J. O'Loughlin and J. H. Terry for assistance with XAFS measurements.

\section{Literature Cited}

(1) Nealson, K.; Myers, C. R. Appl. Environ. Microbiol. 1992, 58, $439-443$.

(2) Lovley, D. R. Annu. Rev. Microbiol. 1993, 47, 263-290.

(3) Nealson, K.; Saffarini, D. Annu. Rev. Microbiol. 1994, 48, 311343.
(4) Lovley, D. R.; Phillips, E. J. P.; Gorby, Y. A.; Landa, E. R. Nature 1991, 350, 413-416.

(5) Gorby, Y. A.; Lovley, D. R. Environ. Sci. Technol. 1992, 26, 205207.

(6) Lovley, D. R.; Phillips, E. J. P. Environ. Sci. Technol. 1992, 26 2228-2234.

(7) Shen, H.; Wang, Y. T. J. Environ. Qual. 1994, 120, 560-572.

(8) Gorby, Y. A.; Caccavo, F.; Drektrah, D. B.; Bolton, H. Environ. Sci. Technol. 1998, 32, 244-250.

(9) Brooks, S. C.; Carroll, S. L.; Jardine, P. M. Environ. Sci. Technol. 1999, 33, 3002-3011.

(10) Lloyd, J. R.; Thomas, G. H.; Finley, J. A.; Cole, J. A.; Macaskie, L. E. Biotechnol. Bioeng. 1999, 66, 122-130.

(11) Wildung, R. E.; Gorby, Y. A.; Krupka, K. M.; Hess, N. J.; Li, S. W.; Plymale, A. E.; McKinley, J. P.; Fredrickson, J. K. Appl. Environ. Microbiol. 2000, 66, 2451-2460.

(12) Fredrickson, J. K.; Kostandarithes, H. M.; Li, S. W.; Plymale, A. E.; Daly, M. J. Appl. Environ. Microbiol. 2000, 66, 2006-2011.

(13) Ganesh, R.; Robinson, K. G.; Reed, G. D.; Sayler, G. S. Appl. Environ. Microbiol. 1997, 63, 4385-4391.

(14) Phillips, E. J. P.; Landa, E. R.; Lovely, D. R. J. Ind. Microbiol. 1995, 14, 203-207.

(15) Robinson, K. G.; Ganesh, R.; Reed, G. D.; Kucsmas, D. A. In Proceedings of the 67th Annual Water Environment Federation Conference; Water Environment Federation: Chicago, IL, 1994; pp 199-208.

(16) Wielinga, B. E.; Bostick, B.; Hansel, C. M.; Rosenzweig, R. F.; Fendorf, S. Environ. Sci. Technol. 2000, 34, 2190-2195.

(17) Liu, C.; Zachara, J. M.; Fredrickson, J. K.; Kennedy, D. W.; Dohnalkova, A. Environ. Sci. Technol. 2002, 36, 1452-1459.

(18) Fredrickson, J. K.; Zachara, J. M.; Kennedy, D. W.; Liu, C.; Duff, M. C.; Hunter, D. B.; Dohnalkova, A. Geochim. Cosmochim. Acta 2002, 66, 3247-3262.

(19) Clark, D. L.; Hobart, D. E.; Neu, M. P. Chem. Rev. 1995, 95, 25-48.

(20) Abdelouas, A.; Lutze, W.; Nuttall, E. J. Contam. Hydrol. 1998, 34, 343-361.

(21) Bernhard, G.; Geipel, G.; Brendler, V.; Nitsche, H. Radiochim. Acta 1996, 74, 87-91.

(22) Kalmykov, S. N.; Choppin, G. R. Radiochim. Acta 2000, 88, 603606.

(23) Bernhard, G.; Geipel, G.; Reich, T.; Brendler, V.; Amayri, S.; Nitsche, H. Radiochim. Acta 2001, 89, 511-518.

(24) Fredrickson, J. K.; Zachara, J. M.; Kennedy, D. W.; Dong, H.; Onstott, T. C.; Hinman, N. W.; Li, S. W. Geochim. Cosmochim. Acta 1998, 62, 3239-3257.

(25) Lovley, D. R.; Phillips, E. J. P. Appl. Environ. Microbiol. 1988, $54,1472-1480$.

(26) Tribalat, S.; Beydon, J. Anal. Chim. Acta 1953, 8, 22-28.

(27) Segre, C. U.; Leyarovska, N. E.; Chapman, L. D.; Lavender, W. M.; Plag, P. W.; King, A. S.; Kropf, A. J.; Bunker, B. A.; Kemner, K. M.; Dutta, P.; Druan, R. S.; Kaduk, J. In Synchrotron Radiation Instrumentation: Eleventh U.S. Conference; Pianetta, P., Ed.; American Institute of Physics: New York, 2000; Vol. CP521, pp $419-422$.

(28) Stern, E. A.; Newville, M.; Ravel, B.; Yacoby, Y.; Haskel, D. Physica B 1995, 208-209, 117-120.

(29) Newville, M. J. Synchrotron Radiat. 2001, 8, 322-324.

(30) Ravel, B. http://leonardo.phys.washington.edu/ ravel/software/ exafs/ (accessed February 20, 2003).

(31) Zabinsky, S. I.; Rehr, J. J.; Ankudinov, A.; Albers, R. C.; Eller, M. J. Phys. Rev. B 1995, 52, 2995-3009.

(32) Coda, A.; Della-Giusta, A.; Tazzoli, V. Acta Crystallogr. 1981 B37, 1496-1500.

(33) Newville, M.; Ravel, B.; Haskel, D.; Stern, E. A. Physica B 1995 208/209, 154-156.

(34) Kelly, S. D.; Kemner, F. M.; Fein, J. B.; Fowle, D. A.; Boyanov, M. I.; Bunker, B. A.; Yee, N. Geochim. Cosmochim. Acta 2002 66, 3855-3871.

(35) Kelly, S. D.; Newville, M. G.; Cheng, L.; Kemner, K. M.; Sutton, S. R.; Fenter, P.; Sturchio, N. C.; Spötl, C. Environ. Sci. Technol. 2003, 37, 1284-1287.

(36) Bethke, C. M. The Geochemist's Workbench; University of Illinois: 1994

(37) Grenthe, I.; Fuger, J.; Konings, R. J. M.; Lemire, R. J.; Muller, A. B.; Cregu, C. N. T.; Wanner, H. Chemical Thermodynamics of Uranium; North-Holland: Amsterdam, 1992.

(38) Shock, E. L.; Koretsky, C. M. Geochim. Cosmochim. Acta 1993, 57, 4899-4922.

(39) Kelly, S. D.; Newville, M. G.; Cheng, L.; Kemner, K. M.; Sutton, S. R.; Fenter, P.; Sturchio, N. C.; Spötl, C. Submitted for publication in Environ. Sci. Technol. 
(40) Liu, C.; Gorby, Y. A.; Zachara, J. M.; Fredrickson, J. K.; Brown, C. F. Biotechnol. Bioeng. 2002, 80, 637-649.

(41) Zhang, C. L.; Brooks, S. C.; Jardine, P. M.; Vali, H. Presented at the National Conference on Environmental Science and Technology, Greensboro, NC, 2002.

(42) Caccavo, F.; Lonergan, J.; Lovley, D. R.; Davis, M.; Stoltz, J. F.; Mclnerney, J. Appl. Environ. Microbiol. 1994, 60, 3752-3759.

(43) Wielinga, B.; Mizuba, M. M.; Hansel, C. M.; Fendorf, S. Environ. Sci. Technol. 2001, 35, 522-527.

(44) Workman, D. J.; Woods, S. L.; Gorby, Y. A.; Fredrickson, J. K.; Truex, M. J. Environ. Sci. Technol. 1997, 31, 2292-2297.

(45) Balch, W. E.; Fox, G. E.; Margrum, L. J.; Woese, C. R.; Wolfe, R. S. Microbiol. Rev. 1979, 43, 260-296.

(46) Tsapin, A. I.; Nealson, K. H.; Myers, T.; Cusanovich, M. A.; Beuumen, J. V.; Crosby, L. D.; Feinberg, B. A.; Zhang, C. J. Bacteriol. 1996, 178, 6386-6388.
(47) Bruschi, M.; Loutfi, M.; Bianco, P.; Haladjian, J. Biochem. Biophys. Res. Commun. 1984, 120, 384-389.

(48) Seeliger, S.; Cord-Ruwisch, R.; Schink, B. J. Bacteriol. 1998, 180, 3686-3691.

(49) Landa, E. R. Uranium 1982, 1, 53-64.

(50) Lemire, R. J.; Jobe, D. J. In Scientific Basis for Nuclear Waste Management XIX; Murphy, W. M., Knecht, D. A., Eds.; Materials Research Society Symposium Proceedings, Boston, MA, 1995; Vol. 412, pp 873-880.

Received for review October 28, 2002. Revised manuscript received February 25, 2003. Accepted February 26, 2003.

ES0210042 